\title{
Erratum: Development of a multi-electrode array for spinal cord epidural stimulation to facilitate stepping and standing after a complete spinal cord injury in adult rats
}

Parag Gad ${ }^{1,3+}$, Jaehoon Choe ${ }^{2,3 \dagger}$, Mandheerej Singh Nandra ${ }^{7 \dagger}$, Hui Zhong ${ }^{3 \dagger}$, Roland R Roy ${ }^{3,6 \dagger}$, Yu-Chong Tai ${ }^{7,8,9 \dagger}$ and V Reggie Edgerton ${ }^{3,4,5^{*}+}$

\section{Erratum}

The authors would like to issue an erratum for this article [1], and would like to declare the following competing interests which we inadvertently failed to include in our original publication. The authors would like to apologise for this omission.

\section{Competing interests}

Dr V. Reggie Edgerton and Dr Roland Roy, researchers on the study team, hold shareholder interests in NeuroRecovery Technologies. Dr Edgerton is also President and Chair of the company's Board of Directors. Dr Edgerton and Dr Roy hold certain inventorship rights on intellectual property licensed by The Regents of the University of California to NeuroRecovery Technologies and its subsidiaries. No other authors have competing interests.

\section{Author details}

'Biomedical Engineering IDP, University of California, Los Angeles, CA 90095 USA. ${ }^{2}$ Neuroscience IDP, University of California, Los Angeles, CA 90095, USA. ${ }^{3}$ Department of Integrative Biology and Physiology, University of California, Terasaki Life Sciences Building, 610 Charles E. Young Drive East, Los Angeles, CA 90095-7239, USA. ${ }^{4}$ Department of Neurobiology, University of California, Los Angeles, CA 90095, USA. ${ }^{5}$ Department of Neurosurgery, University of California, Los Angeles, CA 90095, USA. 'Brain Research Institute, University of California, Los Angeles, CA 90095, USA. ${ }^{7}$ Department of Electrical Engineering, California Institute of Technology, Pasadena, CA 91125, USA. ${ }^{8}$ Department of Mechanical Engineering, California Institute of Technology, Pasadena, CA 91125, USA. 'Department of Bioengineering, California Institute of Technology, Pasadena, CA 91125, USA

* Correspondence: vre@ucla.edu

${ }^{\dagger}$ Equal contributors

${ }^{3}$ Department of Integrative Biology and Physiology, University of California, Terasaki Life Sciences Building, 610 Charles E. Young Drive East, Los Angeles, CA 90095-7239, USA

${ }^{4}$ Department of Neurobiology, University of California, Los Angeles, CA 90095, USA

Full list of author information is available at the end of the article
Received: 16 February 2015 Accepted: 19 February 2015 Published online: 29 March 2015

\section{Reference}

1. Gad P, Choe J, Nandra MS, Zhong H, Roy RR, Tai YC, et al. Development of a multi-electrode array for spinal cord epidural stimulation to facilitate stepping and standing after a complete spinal cord injury in adult rats. J Neuroeng Rehabil. 2013;10:2.
Submit your next manuscript to BioMed Central and take full advantage of:

- Convenient online submission

- Thorough peer review

- No space constraints or color figure charges

- Immediate publication on acceptance

- Inclusion in PubMed, CAS, Scopus and Google Scholar

- Research which is freely available for redistribution

Submit your manuscript at www.biomedcentral.com/submit
() Biomed Central
Biomed Central (c) 2015 Gad et al.; licensee BioMed Central. This is an Open Access article distributed under the terms of the Creative Commons Attribution License (http://creativecommons.org/licenses/by/4.0), which permits unrestricted use, distribution, and reproduction in any medium, provided the original work is properly credited. The Creative Commons Public Domain Dedication waiver (http://creativecommons.org/publicdomain/zero/1.0/) applies to the data made available in this article, unless otherwise stated. 